\title{
Het MAB vóór 50 jaar
}

december 1938

M. Pimentel geeft zijn indrukken van de Efficiency-tentoonstelling, welke om de drie jaar wordt gehouden door de Vereeniging van Importeurs en Fabrikanten van kantoormachines.

De schrijver constateert, dat overal waar een enigzins omvangrijke administratie nog met de hand wordt bijgehouden, de boekhouders en andere kantoorbedienden heel veel 'machinaal schrijf- en telwerk en overschrijf- en natelwerk' met de hand verrichten, hetgeen veel tijd kost, zodat zij slechts een klein percentage van hun tijd kunnen besteden 'aan werkelijk intellectuele arbeid'.

Pimentel acht de technische ontwikkeling in de machines (zowel boekhoudmachines als schrijf-, tel- en rekenmachines en duplicators) reeds zover gevorderd, dat er nog weinig nieuws op dit gebied te verwachten valt. Over de ontwikkelingen in het ponskaartensysteem is Pimentel bijna net zo lyrisch als Groot zich uitdrukte in zijn artikel enige maanden daarvoor (zie historisch verslag juli 1988).

In de rubriek 'Boekbespreking' behandelt Prof. Mr. H.W.C. Bordewijk het utopisch getinte werk 'De beheersching der Wereldeconomie' van Dr. W.L. Valk (niet te verwarren met Dr. H.M.H.A. van der Valk-AFT). Volgens de auteur behelst zijn boek 'een onderzoek betreffende de voorwaarden van stabiele welvaart en wereldvrede'. Bordewijk vindt dat het gedragen wordt door de vurige wens door bezinning en bezonnen propaganda te komen tot betere toestanden op conjunctureel gebied en het heeft bij alle theorie toch een praktische strekking vol hervormingsdrang.

Het motto van het boek luidt:

'Werk voor de arbeiders

Zekerheid voor de beleggers

Centraal gezag bij maximale vrijheid

Vrede en goede wil onder de volken

Welvaart voor allen.'

Bordewijk noemt deze de vijf zaligheden. Hij vraagt zich af of de schrijver niet vijf poten aan een schaap verlangt. 
Op zijn bekende fijnzinnige wijze weerlegt Bordewijk veel van wat Valk als middel aanbeveelt; de weerlegging gaat veelal gepaard met lovende woorden, die eindigen met de opmerking, dat de idealen niet uitvoerbaar zijn.

Het is na 50 jaar nog altijd boeiend hoe Bordewijk zich - ook voor onze tijd kan uitdrukken, zoals:

- Ook op sociaal-economisch gebied valt het minder moeilijk velen voor idealen te winnen naarmate deze vager zijn en de wegen daarheen meer aan het oog zijn onttrokken.

- De verdeeldheid steekt als een Lernaeische draak haar koppen op zodra doeleinden en middelen voor het forum der bewustwording verschijnen en een wetenschappelijk en praktisch verantwoorde keuze moet worden gedaan.

- Meer en meer worden de individuen tot zwakkelingen gemaakt door velerlei wanbegrip, o.a. inzake het winststreven en zijn oorbaarheid, de juistheid - in beginsel - van concurrentie, de constitutionele vrijheid in beroep en bedrijf, 'al te gader elementen van risico, die, mits zelf gedragen, het individu sterker maken'.

- De wetenschap gaat er niet op vooruit, naarmate zij tot een soort receptuurboek wordt voor onmiddellijke assistentie. Causale wetenschap verdraagt zich niet met eisen van rechtstreekse resultaten. De omgang tussen de theoretische regel en de normatieve stelregel behoort tot het strijdperk der politiek, die bruggen bouwt tussen waarheid en doelmatigheid.

- Voor alle hervormingsgedachten geldt dat wij wel weten wat wij hebben, maar ondanks alle kritiek op het bestaande, toch stellig niet wat wij krijgen.

- Waarom zou men voor het herstel van verbroken evenwicht moeten wachten op ordening van buiten? Voor sommige ziektes is toch alleen herstel mogelijk bij enig vertrouwen in de kracht in het organisme zelf. Niets treft wellicht meer in deze tijd (de gevolgen van de crisis in de dertiger jaren waren nog lang niet verdreven - AFT) dan de ongeneigdheid tot geloof in de krachten tot herstel en de daartoe nodige offers te aanvaarden. Voor de gevolgen van het laten doorzieken schrikt onze tijd zo gauw terug. J'y suis, j'y reste kan, in deze tijd van protectie, ieder zeggen die een economisch bestaantje heeft. De vrijheid die het risico van to be or not to be de ware ondernemer verschaft en waarnaar hij verlangt - ook al mocht het misgaan - heeft meer en meer plaats gemaakt voor een vrijheidrovende waarborging van ordeningsgarantie en handen ophouden.

Bordewijk eindigt zijn boekbespreking met de opmerking dat het boek elke aansluiting aan het historisch gewordene mist. Dat is volgens hem het grootste bezwaar tegen proefnemingen op praktisch-economisch gebied. 